\title{
SOIL MICROBIOLOGICAL ACTIVITY AND PRODUCTIVITY OF MAIZE FODDER WITH LEGUMES AND MANURE DOSES ${ }^{1}$
}

\author{
CHARLLEY DE FREITAS SILVA ${ }^{2}$, ERIKA VALENTE DE MEDEIROS ${ }^{2 *}$, MARTHONY DORNELAS SANTANA ${ }^{2}$, \\ MAYSA BEZERRA DE ARAÚJO' ${ }^{2}$, ARGEMIRO PEREIRA MARTINS FILHO ${ }^{3}$, MÁCIO FARIAS DE MOURA $^{2}$
}

\begin{abstract}
Maize is an important cereal and it is widely consumed in the world, both as food for humans and animals. Nitrogen $(\mathrm{N})$ is a nutrient required in large quantities by maize, but unfortunately, soils are limited in meeting this need. Nodulating legumes can serve as a source of Nitrogen, because they are symbiotically associated with bacteria capable of fixing atmospheric N. Another important source of this nutrient is cattle manure, which is widely used in agriculture. The objective of the present study was to evaluate the effect of using legumes and cattle manure on the production as well as the microbial and biochemical quality of the soil used for maize cultivation. The experiment was conducted using a randomized complete block design, in a sub-subdivided plot scheme $[(2 \times 4)+2]$, two leguminous plants (pigeon pea and macassar bean), four doses of cattle manure $\left(0,20,40\right.$ and $\left.60 \mathrm{t} \mathrm{ha}^{-1}\right)$ and two controls; one with mineral fertilization and the other cultivated without the use of fertilizers. Treatment using a manure dose of $60 \mathrm{t}$ ha-1 and pigeon pea legume, recorded higher dry mass production per plant. The increase in manure doses was directly proportional to the length and weight of the cobs for the two legumes. The enzymatic activities were affected by the different doses and legumes, with greater results being recorded at the $60 \mathrm{t} \mathrm{ha}^{-1}$ dose with the macassar legume. The use of legumes with manure improved maize production as well as the microbiological and biochemical quality of soils.
\end{abstract}

Keywords: Zea mays. Green manure. Enzyme.

\section{ATIVIDADE MICROBIOLÓGICA DO SOLO E PRODUTIVIDADE DO MILHO ADUBADO COM LEGUMINOSAS E DOSES DE ESTERCO}

\begin{abstract}
RESUMO - O milho é um importante cereal muito utilizado no mundo, tanto como alimentação para humanos como para animais. O nitrogênio $(\mathrm{N})$ é um nutriente requerido em grande quantidade pelo milho, e os solos são limitantes em atender essa necessidade. As leguminosas nodulantes podem ser utilizadas como fonte de Nitrogênio, por formarem associações simbióticas com bactérias capazes de fixar $\mathrm{N}$ atmosférico, outra importante fonte desse nutriente é o esterco bovino, utilizado largamente na agricultura. O objetivo do presente estudo foi avaliar o efeito do uso de leguminosas e esterco bovino na produção e qualidade microbiana e bioquímica do solo cultivado com milho. O experimento foi conduzido em delineamento de blocos ao acaso, em esquema de parcela sub-subdividida $[(2 \times 4)+2]$, sendo duas leguminosas (feijão guandu anão e feijão macassar), quatro doses de esterco bovino $\left(0,20,40\right.$ e $\left.60 \mathrm{t} \mathrm{ha}^{-1}\right)$, mais dois tratamentos controle um com adubação mineral e outro sem o emprego de adubos. $O$ tratamento utilizando a dose $60 \mathrm{t} \mathrm{ha}^{-1}$ de esterco com a leguminosa Guandu anão apresentou maior produção de massa seca por planta. $\mathrm{O}$ aumento das doses de esterco foi diretamente proporcional ao comprimento e peso das espigas para as duas leguminosas. As atividades enzimáticas responderam às diferentes doses e leguminosas, com maiores resultados na dose de $60 \mathrm{t} \mathrm{ha}^{-1} \mathrm{com} \mathrm{a}$ leguminosa macassar. O uso de leguminosa com esterco melhorou a produção de milho e a qualidade microbiológica e bioquímica dos solos.
\end{abstract}

Palavras-chave: Zea mays. Adubação verde. Enzimas.

\footnotetext{
${ }^{*}$ Corresponding author

${ }^{1}$ Received for publication in 08/25/2017; accepted in 01/22/2018.

Paper extracted from project of microbial ecology of the soil-plant system discipline.

${ }^{2}$ Academic Unit of Garanhuns, Universidade Federal Rural de Pernambuco, Garanhuns, PE, Brasil; charlleyfs@hotmail.com - ORCID: 0000-0001-7502-0725, evmbio@gmail.com - ORCID: 0000-0001-5543-9414, marthony1992@ hotmail.com - ORCID: 0000-0003-0798018X, maysa_araujo@hotmail.com - ORCID: 0000-0001-5843-0781, maciof@yahoo.com.br - ORCID:0000-0002-3347-2368.

${ }^{3}$ Departament of Plant Sciences, Universidade Federal de Viçosa, Viçosa, MG, Brasil; argemiro.ufra@gmail.com - ORCID: 0000-00033199-2703.
} 


\section{INTRODUCTION}

Maize (Zea mays L.) is of great economic importance in Brazil, as well as in other parts of the world due to the nutritional value of its grains and its intense use for human and animal consumption. In addition, it is important as a raw material for industry and social value for being a food of low cost, and it is viable for cultivation both in large and small scales (SOUZA; BRAGA; CUNHA, 2010).

Globally, USDA's (2016) forecast for the maize crop was 4.8 million tonnes $(\mathrm{t})$, with global cereal production at 1.03 billion tonnes, a record volume of more than 71.4 million tonnes for $2015 / 16$. The global consumption was also projected at 1.02 billion tonnes, up from 44.5 million tonnes in $2015 / 16$. With the increase in supply being above the global demand, the final inventories increased from October to November, totaling 218.2 million tonnes.

Despite being cultivated on a large commercial scale, it is necessary to improve the maize production system, aiming at greater efficiency and sustainability of the production process. In the soil-plant system, there are several measures capable of increasing production. Among the alternatives, the use of green manure is a viable way of mitigating the impacts of agriculture, increasing production and sustainability to agricultural soils (ROSA et al., 2011).

In this sense, the use of green manures is of vital importance for the recovery and maintenance of the chemical, physical, biological and biochemical attributes of the soil. The legumes used as green manure increase the soil biomass and reflect the yield of subsequent crops, promote increased availability of nutrients and the ability to exchange effective cations of the soil (ALCÂNTARA et al., 2000). In addition, it increases the availability of $C$ in the medium, thereby promoting the growth of microbial biomass and increasing the production and activity of extracellular enzymes (BURNS et al.,
2013). Thus, biological indicators of soil quality such as microbial biomass and enzymatic activity may be better indicators, as they respond faster to environmental and anthropogenic changes (MEDEIROS et al., 2015).

Microbial biomass carbon (MBC) is used as an indicator capable of showing changes in soil use quality. According to Cunha et al. (2011), MBC is the main fraction of soil organic matter, as a result of the vital role of microorganisms in organic waste decomposition, nutrient cycling and soil energy flux. Several studies have confirmed the efficiency of using MBC and soil enzymatic activities as a "measuring instrument" for evaluating the changes occurring in agroecosystems (BELO et al., 2012; MEDEIROS et al., 2017).

As a result of the increasing search for alternative forms of organic fertilization in maize crop and the sensitivity of some biological and biochemical attributes of the soil that can provide the producer with faster tools for detecting the quality of soils with green manures, the objective of this study was to evaluate the effect of fertilization with different legumes and doses of cattle manure on maize production and the effect on the microbial and biochemical quality of a sandy soil.

\section{MATERIAL AND METHODS}

This experiment was conducted in the field of Garanhuns - PE, Northeast of Brazil at the Experimental Farm (UFRPE / UAG) (08 58'28 "S and $36^{\circ} 27^{\prime} 11^{\prime \prime} \mathrm{O}$ ), with an altitude of $736 \mathrm{~m}$. Based on Köppen's classification, the region has a tropical semiarid (BSh) climate. According to the classification system of EMBRAPA, the soil is a Yellow Latosol, with a true sandy characteristic. Prior to the experiment, soil samples were collected and sent to the laboratory for chemical and physical characterization (Table 1).

Table 1. Chemical and physical characterization of the Yellow Latosol used in the experiment of nodulant legumes and manure in maize production.

\begin{tabular}{|c|c|c|c|c|c|c|c|c|c|c|c|}
\hline \multirow{2}{*}{$\mathrm{P} \mathrm{mg} / \mathrm{dm}^{3}$} & \multirow[b]{2}{*}{$\mathrm{pH}\left(\mathrm{H}_{2} \mathrm{O}\right)$} & \multicolumn{8}{|c|}{$\mathrm{cmol} \mathrm{dm}^{-3}$} & \multicolumn{2}{|c|}{$\%$} \\
\hline & & $\mathrm{Ca}$ & $\mathrm{Mg}$ & $\mathrm{Na}$ & $\mathrm{K}$ & $\mathrm{Al}$ & $\mathrm{H}$ & $\mathrm{S}$ & CEC & V & $\mathrm{m}$ \\
\hline 2 & 5.59 & 2.75 & 0.75 & 0.05 & 0.21 & 0 & 3.38 & 3.80 & 7.10 & 53 & 0 \\
\hline \multicolumn{2}{|c|}{ Density $\left(\mathrm{g} \mathrm{cm}^{-3}\right)$} & \multicolumn{6}{|c|}{ Granulometric composition } & & \multicolumn{3}{|c|}{ Textural class } \\
\hline Dap & Dr & \multicolumn{2}{|c|}{ Coarse sand } & \multicolumn{2}{|c|}{$\begin{array}{l}\text { Sand } \\
\text { slim }\end{array}$} & Silte & & Clay & & & \\
\hline 1.36 & 2.53 & \multicolumn{2}{|c|}{46} & \multicolumn{2}{|c|}{20} & 8 & & 26 & \multicolumn{3}{|c|}{$* \mathrm{SF}$} \\
\hline
\end{tabular}

$* \mathrm{SF}=$ Sandy franc; $\mathrm{CEC}=$ cation exchange capacity.

The maize variety used in this experiment was CMS-36 and it was developed by EMBRAPA. Macassar bean and dwarf pigeon pea were sown at a spacing of $0.3 \mathrm{~m}$ between rows. Twelve (12) seeds were sown per linear meter for pigeon pea while 8 seeds were sown for macassar beans. These legumes constituted one per plot and were incorporated during the flowering period. In the 
subplot, four doses of cattle manure $(0,20,40$ and $60 \mathrm{t} \mathrm{ha}^{-1}$ ) were collected at the UFRPE Cattle Clinic. The application of cattle manure was performed 30 days before sowing.

Maize seeds were sown at a spacing of $0.8 \times 0.2 \mathrm{~m}$, seven rows of 15 plants each, totaling 105 plants per plot. The central lines were the basis for the data analysis of the experiment. The seed distribution was manual, placing two seeds per pit every $0.2 \mathrm{~cm}$ within the row. When the plants were in the phenological stage of three expanded leaves (V3), according to the scale proposed by Ritchie, Hanway and Benson (1993), thinning was performed, leaving one plant per pit. Weeds were controlled by hand weeding.

The experiment was conducted using a randomized complete block design, in a sub-subdivided plot scheme $[(2 \times 4)+2]$, two leguminous plants (pigeon pea and macassar bean), four doses of cattle manure $\left(0,20,40\right.$ and $\left.60 \mathrm{tha}^{-1}\right)$, plus two additional control treatments one with NPK fertilizer and another without the use of fertilizers.

On the same day of plant evaluation, soil samples were collected and sent to the Enzyme and Environmental Microbiology laboratory of the Federal Rural University of Pernambuco, where $\mathrm{MBC}$ and enzymatic activities were analyzed. For the determination of $\mathrm{MBC}$, the soil samples were submitted to the irradiation process according to Mendonça and Matos (2005). A $0.5 \quad \mathrm{M} \mathrm{K} \mathrm{K}_{2} \mathrm{SO}_{4}$ extractor was utilized for biomass extraction. For each $20 \mathrm{~g}$ of soil, $80 \mathrm{~mL}$ of $0.5 \mathrm{M} \mathrm{K}_{2} \mathrm{SO}_{4}$ was added. The carbon in the extracts was determined by colorimetry.

Urease activity (URE) was determined according to Kandeler and Gerber (1988), and it involved incubation for 2 hours at $37^{\circ} \mathrm{C}$. The results were expressed as $\left(\mu \mathrm{g} \mathrm{NH}_{4}-\mathrm{N} \mathrm{g}^{-1}\right.$ soil $\left.\mathrm{h}^{-1}\right)$. The analyses were performed in triplicate of each replicate.

Acid and alkaline phosphatase activities (Pac and Palk) were estimated as adapted from Tabatabai (1994). To $1 \mathrm{~g}$ of soil samples, $4 \mathrm{~mL}$ of MUB buffer ( $\mathrm{pH}$ 6.5) were added to perform the acid phosphatase activity and $4 \mathrm{~mL}$ of MUB buffer ( $\mathrm{pH} 11)$ to perform the alkaline phosphatase activity. The reading was done at $400 \mathrm{~nm}$ absorbance. The standard curve was taken from a stock solution, following the same procedure adopted in relation to the samples. The analyses were performed in triplicate of each replicate.

Data were submitted for analysis of variance (ANOVA) and the means were compared by Dunnett's test at $5 \%$ probability. To study the doses of organic compounds, polynomial regression analysis was performed, the model with the highest significant degree that allows the explanation of biological phenomena and which had a coefficient of determination higher than $50 \%$, was chosen. Statistical analyses were conducted using the SAS software

\section{RESULTS AND DISCUSSION}

When compared to mineral treatment, maize plants cultivated with green manure (nodulant legumes) and manure doses, did not show significant difference for the variables: cob/plant, weight of one hundred grains, cob diameter, number of rows of grain, weight of cob and height of plants, the latter being a genetic characteristic influenced by the environment in which the plant develops (Table 2). This fact was also verified by Rosa et al. (2011) in studies with cover plants, in which there was no significant difference for plant height and height of cob insertion, corroborating the results found in this work.

According to Boddey et al. (2010), the legumes used as green fertilizers promote carbon accumulation in the soil, a fact explained by the slow release of nitrogen from these residues, and this favors the growth of maize roots. This favors root growth and may affect plant height growth, and this fact may explain the results found in the present study.

On the other hand, for the variables cob length and plant dry matter, the results obtained showed that the $0 \mathrm{t} \mathrm{ha}^{-1}$ dose of macassar, showed significantly lower cob growth compared to that observed in the mineral fertilization treatment Whereas, the $60 \mathrm{t} \mathrm{ha}^{-1}$ treatment was significantly higher $(\mathrm{p}<0.05)$ compared to the mineral fertilizer treatment for the characteristic plant dry matter (Table 2). Also, Doan et al. (2015) recorded higher values of maize dry mass, when they were cultivated with organic fertilizer compared to mineral fertilizer.

The present study clearly indicates that the use of organic and green fertilizers made it possible to obtain maize plants with dry biomass production and cob length higher than those produced using a mineral fertilizer.

In comparison with the absolute control (without fertilizer), the variables that presented a significant difference were: plant height $\left(20 \mathrm{t} \mathrm{ha}^{-1}\right.$ pigeon), number of cob / plant (60 t ha ${ }^{-1}$ macassar), length of cob and number of rows of grains with best results of $14.18 \mathrm{~cm}$ and 12.92 , respectively $\left(60 \mathrm{t} \mathrm{ha}^{-1}\right.$ pigeon pea) and plant dry matter, with a best result of $1.07 \mathrm{~kg}^{-1}$ (dose $60 \mathrm{t} \mathrm{ha}^{-1}$ pigeon pea) (Table 3 ). This shows that legumes in association with cattle manure, positively influenced these variables, with no significant difference in the weight of one hundred grains and weight of cobs. Some studies using organic fertilization showed that the effect on the agronomic characteristics of plants is positive and residual, obtaining higher yields with the use of mineral fertilization at third crop cycle (WALTER et al., 2009). 
C. F. SILVA et al.

Table 2. Characteristics of maize cultivated with mineral nutrition in comparison to those produced with legumes associated to cattle manure doses.

\begin{tabular}{|c|c|c|c|c|c|c|c|c|}
\hline Trat. & $\mathrm{PH}(\mathrm{m})$ & $\mathrm{NCP}$ & $\begin{array}{c}\text { W100G } \\
(\mathrm{g})\end{array}$ & $\mathrm{CD}(\mathrm{cm})$ & LC $(\mathrm{cm})$ & NR & $\begin{array}{l}\mathrm{CW} \\
(\mathrm{Kg})\end{array}$ & $\begin{array}{c}\text { PDM } \\
(\mathrm{Kg})\end{array}$ \\
\hline MIN & 2.05 & 1.13 & 25.96 & 3.49 & 13.48 & 12.10 & 1.98 & 0.64 \\
\hline $0-\mathrm{M}$ & $1.65^{\mathrm{ns}}$ & $0.73^{\mathrm{ns}}$ & $27.42^{\mathrm{ns}}$ & $3.26^{\mathrm{ns}}$ & $9.89 *$ & $11.41^{\mathrm{ns}}$ & $1.27^{\mathrm{ns}}$ & $0.49^{\mathrm{ns}}$ \\
\hline 20-M & $1.86^{\mathrm{ns}}$ & $0.90^{\mathrm{ns}}$ & $25.19^{\mathrm{ns}}$ & $3.40^{\mathrm{ns}}$ & $10.65^{\mathrm{ns}}$ & $11.77^{\mathrm{ns}}$ & $1.60^{\mathrm{ns}}$ & $0.63^{\mathrm{ns}}$ \\
\hline 40-M & $2.05^{\mathrm{ns}}$ & $0.97^{\mathrm{ns}}$ & $27.65^{\mathrm{ns}}$ & $3.55^{\mathrm{ns}}$ & $12.44^{\mathrm{ns}}$ & $12.06^{\mathrm{ns}}$ & $1.83^{\mathrm{ns}}$ & $0.81^{\mathrm{ns}}$ \\
\hline 60-M & $2.03^{\mathrm{ns}}$ & $1.00^{\mathrm{ns}}$ & $28.56^{\mathrm{ns}}$ & $3.52^{\mathrm{ns}}$ & $13.69^{\mathrm{ns}}$ & $11.90^{\mathrm{ns}}$ & $1.82^{\mathrm{ns}}$ & $0.90^{\mathrm{ns}}$ \\
\hline $0-\mathrm{G}$ & $1.57^{\mathrm{ns}}$ & $0.77^{\mathrm{ns}}$ & $24.77^{\mathrm{ns}}$ & $3.24^{\mathrm{ns}}$ & $11.66^{\mathrm{ns}}$ & $10.96^{\mathrm{ns}}$ & $1.47^{\mathrm{ns}}$ & $0.44^{\mathrm{ns}}$ \\
\hline $20-\mathrm{G}$ & $2.57^{\mathrm{ns}}$ & $0.80^{\mathrm{ns}}$ & $24.95^{\mathrm{ns}}$ & $3.33^{\mathrm{ns}}$ & $11.15^{\mathrm{ns}}$ & $11.57^{\mathrm{ns}}$ & $1.45^{\mathrm{ns}}$ & $0.63^{\mathrm{ns}}$ \\
\hline $40-\mathrm{G}$ & $1.91^{\mathrm{ns}}$ & $0.93^{\mathrm{ns}}$ & $27.23^{\mathrm{ns}}$ & $3.45^{\mathrm{ns}}$ & $12.47^{\mathrm{ns}}$ & $12.46^{\mathrm{ns}}$ & $1.63^{\mathrm{ns}}$ & $0.78^{\mathrm{ns}}$ \\
\hline $60-\mathrm{G}$ & $1.94^{\mathrm{ns}}$ & $0.90^{\mathrm{ns}}$ & $28.13^{\mathrm{ns}}$ & $3.56^{\mathrm{ns}}$ & $14.18^{\mathrm{ns}}$ & $12.92^{\mathrm{ns}}$ & $1.75^{\mathrm{ns}}$ & $1.07 *$ \\
\hline
\end{tabular}

*Significant by the Dunnett test at the $5 \%$ probability level. NS (not significant). PH (plant height). NCP (number of ears / plant). W100G (weight of one hundred grains). CD (cob diameter). LC (length of cob). NR (number of rows of grains). CW (cob weight). PDM (plant dry matter). MIN (Mineral). 0-M. 20-M. 40-M. 60-M (0; 20; 40 and $60 \mathrm{t} \mathrm{ha}^{-1}$ of macassar bean). $0-\mathrm{G} ; 20-\mathrm{G} ; 40-\mathrm{G} ; 60-\mathrm{G}\left(0 ; 20 ; 40\right.$ and $60 \mathrm{t} \mathrm{ha}^{-1}$ of dwarf pigeon pea).

Table 3. Characteristics of maize subjected to absolute control (without fertilizer) compared to those produced with legumes associated with doses of cattle manure.

\begin{tabular}{|c|c|c|c|c|c|c|c|c|}
\hline Trat. & $\mathrm{PH}(\mathrm{m})$ & $\mathrm{NCP}$ & W100G $(\mathrm{g})$ & $\mathrm{CD}(\mathrm{cm})$ & $\mathrm{LC}(\mathrm{cm})$ & NR & $\begin{array}{l}\mathrm{CW} \\
(\mathrm{Kg}) \\
\end{array}$ & $\begin{array}{c}\text { PDM } \\
(\mathrm{Kg}) \\
\end{array}$ \\
\hline $\mathrm{AC}$ & 1.39 & 0.47 & 16.48 & 4.46 & 10.28 & 7.76 & 1.28 & 0.31 \\
\hline $0-\mathrm{M}$ & $1.65^{\mathrm{ns}}$ & $0.73^{\mathrm{ns}}$ & $27.42^{\mathrm{ns}}$ & $3.26^{\mathrm{ns}}$ & $9.89^{\mathrm{ns}}$ & $11.41^{\mathrm{ns}}$ & $1.27^{\mathrm{ns}}$ & $0.49^{\mathrm{ns}}$ \\
\hline 20-M & $1.86^{\mathrm{ns}}$ & $0.90^{\mathrm{ns}}$ & $25.19^{\mathrm{ns}}$ & $3.40^{\mathrm{ns}}$ & $10.65^{\mathrm{ns}}$ & $11.77^{\mathrm{ns}}$ & $1.60^{\mathrm{ns}}$ & $0.63^{\text {ns }}$ \\
\hline 40-M & $2.05^{\mathrm{ns}}$ & $0.97^{\mathrm{ns}}$ & $27.65^{\mathrm{ns}}$ & $3.55^{\mathrm{ns}}$ & $12.44^{\mathrm{ns}}$ & $12.06^{\mathrm{ns}}$ & $1.83^{\mathrm{ns}}$ & $0.81^{*}$ \\
\hline 60-M & $2.03^{\mathrm{ns}}$ & $1.00 *$ & $28.56^{\mathrm{ns}}$ & $3.52^{\mathrm{ns}}$ & $13.69^{*}$ & $11.90^{\mathrm{ns}}$ & $1.82^{\mathrm{ns}}$ & $0.90 *$ \\
\hline $0-\mathrm{G}$ & $1.57^{\mathrm{ns}}$ & $0.77^{\mathrm{ns}}$ & $24.77^{\mathrm{ns}}$ & $3.24^{\mathrm{ns}}$ & $11.66^{\mathrm{ns}}$ & $10.96^{\mathrm{ns}}$ & $1.47^{\mathrm{ns}}$ & $0.44^{\mathrm{ns}}$ \\
\hline $20-\mathrm{G}$ & $2.57 *$ & $0.80^{\text {ns }}$ & $24.95^{\mathrm{ns}}$ & $3.33^{\mathrm{ns}}$ & $11.15^{\mathrm{ns}}$ & $11.57^{\mathrm{ns}}$ & $1.45^{\mathrm{ns}}$ & $0.63^{\mathrm{ns}}$ \\
\hline $40-\mathrm{G}$ & $1.91^{\mathrm{ns}}$ & $0.93^{\mathrm{ns}}$ & $27.23^{\mathrm{ns}}$ & $3.45^{\mathrm{ns}}$ & $12.47^{\mathrm{ns}}$ & $12.46^{*}$ & $1.63^{\mathrm{ns}}$ & $0.78 *$ \\
\hline $60-\mathrm{G}$ & $1.94^{\mathrm{ns}}$ & $0.90^{\mathrm{ns}}$ & $28.13^{\mathrm{ns}}$ & $3.56^{\mathrm{ns}}$ & $14.18 *$ & $12.92 *$ & $1.75^{\mathrm{ns}}$ & $1.07 *$ \\
\hline
\end{tabular}

*Significant by the Dunnett test at the $5 \%$ probability level. NS (not significant). PH (plant height). NCP (number of ears / plant). W100G (weight of one hundred grains). CD (cob diameter). LC (length of cob). NR (number of rows of grains). CW (cob weight). PDM (plant dry matter). AC (absolut control). MIN (Mineral). 0-M. 20-M. 40-M. 60-M (0; 20; 40 and $60 \mathrm{tha}^{-1}$ of macassar bean). 0-G; 20-G; 40-G; 60-G $\left(0 ; 20 ; 40\right.$ and $60 \mathrm{t} \mathrm{ha}^{-1}$ of dwarf pigeon pea)

The use of legumes and doses of manure changed $(p \leq 0.05)$ the cob length per plant, weight of cob per plant and plant dry matter. There was an increase in cob length as the doses of cattle manure were increased, both for macassar legumes and for dwarf pigeon peas, but the pigeon peas yielded a better result $(14.18 \mathrm{~cm})$, which was $3.59 \%$ higher than that obtained in the function of macassar and $5.2 \%$ in the chemical treatment. Therefore, it is important to apply green manure, since when fertilizing with the nodulating legumes, the cob lengths were statistically superior to those obtained using mineral fertilization.

Camara et al. (2016) tested green manure in maize yield and showed a maize cob length of 13.7 $\mathrm{cm}$, using pork bean as cover plant. This corroborates the results found in the present study. However, their findings did not differ statistically from the treatments without fertilizers, which differed from this study since the control treatment (without fertilizer use) was statistically lower. This indicates that the use of dwarf pigeon bean as green manure may be better compared to when pork bean is used for the same purpose. Heinrichs et al. (2003) in their study with maize grown in a conventional system using different levels of nitrogen fertilization, showed cobs length of $14.45 \mathrm{~cm}$. Therefore, the results presented here for the variable cobs length $(14.18 \mathrm{~cm})$ could be similar to the results obtained with mineral fertilization.

The cob length of maize was significantly adjusted $(\mathrm{p} \leq 0.05)$ to a linear equation, whose coefficient of determination showed that the effect of treatments with green manure and manure on the analyzed variable was of the order of $74 \%$ and $97 \%$, for pigeon pea and macassar, respectively (Figure 1). 
C. F. SILVA et al.

- Macassar Pigeon pea

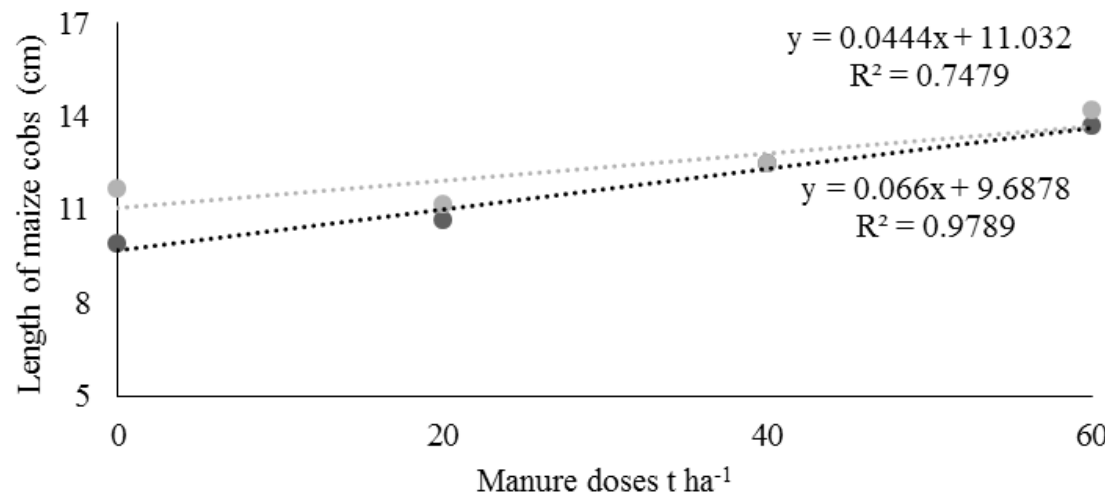

Figure 1. Length of maize cobs as a function of the doses of cattle manure associated with green manure, Macassar and Pigeon pea beans.

The 40-M and 60-M doses provided the highest cob weights, with $1.8 \mathrm{~kg}^{-1}$. The cob weight per plant increased linearly with the addition of manure doses to the macassar legume (Figure 2). However, the values obtained for the dwarf pigeon pea did not conform to the polynomial regression model, but the cob weight per plant showed an average of $1.57 \mathrm{~kg}$. The fact that the macassar legume provides higher cob weight is directly related to the fact that its nitrogen content is higher than pigeon pea, since this element is the one required by maize in higher quantity. Sangoi et al. (2008) showed that this nutrient participates in numerous metabolic routes, among which is the production of grains and consequently, the cob weight. According to Basi et al. (2011), the availability of $\mathrm{N}$ influences the quality of the grains; hence, it is expected that a larger amount of $\mathrm{N}$ will provide a higher cob weight. The study of Cardoso et al. (2010) confirmed the increase in cob weight with the increase in nitrogen supply.

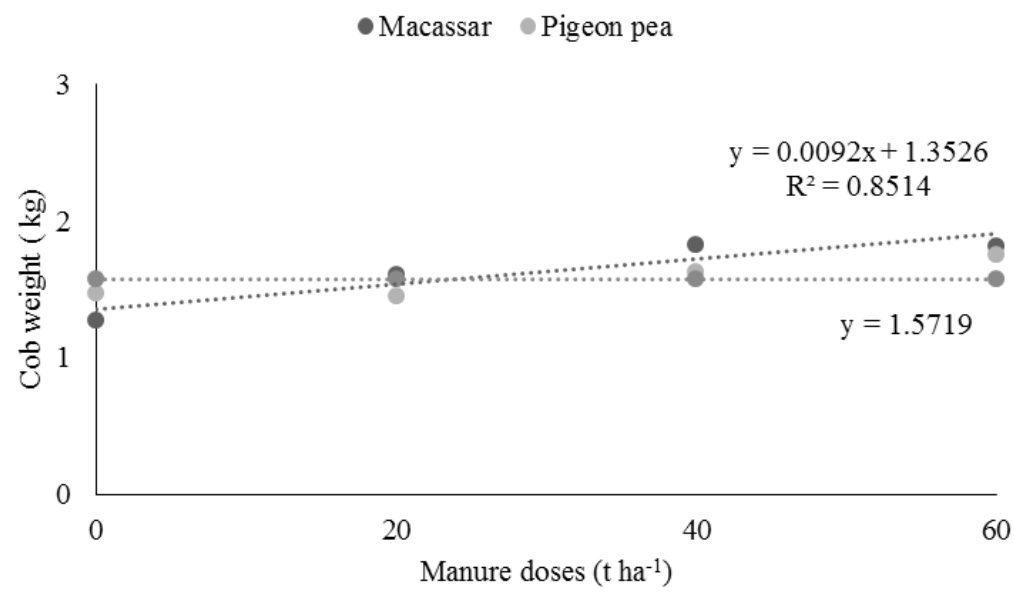

Figure 2. Cob weight per plant according to the doses of cattle manure associated with green manure, Macassar and Pigeon pea beans.

When higher doses of manure were applied, the dry matter of maize plants was higher, and this behavior was similar for both nodulant legumes (Figure 3). However, the application of fertilizer and dwarf pigeon pea at a dose of $60 \mathrm{t} \mathrm{ha}^{-1}$, presented the best increments, with $1.07 \mathrm{~kg}$ per plant (Table 2). These results are related to the fact that macassar beans presented more herbaceous tissues and that it depends on water to remain turgid and erect.
Therefore, it achieves higher production of green biomass and lower production of dry biomass. On the other hand, pigeon pea has a higher proportion of woody tissues, being the reason for attaining a higher dry mass production compared to macassar, since the amount of material incorporated in the soil also influences the characteristics of the main crop, which was maize. 
C. F. SILVA et al.

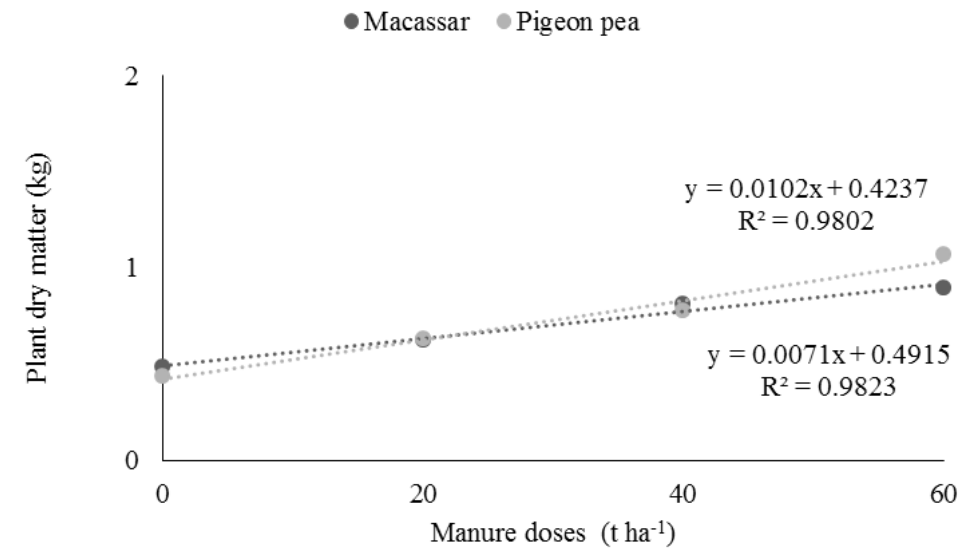

Figure 3. Maize dry matter in the function of cattle manure doses associated with green manure, Macassar and Pigeon pea beans.

The soil MBC increased in the portion treated with green manure (macassar bean), with the highest doses (40 and 60\%) of cattle manure (Figure 4). This increase was progressive during the evaluation, but the legumes showed different responses related to the MBC content. Soil MBC increased at 0 and $60 \%$, for Pigeon pea and Macassar, respectively, compared to chemical and absolute controls.

In the chemical and absolute controls as well as in Pigeon pea beans treatment, the MBC remained stable in all evaluations, regardless of the doses of manure applied. However, macassar beans showed a different behavior, since this indicator remained stable at the initial doses, with an increase in the highest doses.

Soil MBC is the living part of organic matter, and it consists of bacteria, actinomycetes, fungi, protozoa, algae and macrofauna (CHAER; TÓTOLA, 2007). Microbial biomass is a sensitive tool used for the detection of changes in soil as a result of the adopted management (MEDEIROS et al., 2015). In the case of nutritional limitation, the plant can release more root exudates, stimulate microbial biomass, influence the growth of bacteria and fungi that colonize the rhizosphere, which can help plants to acquire nutrients (TROLOVE et al., 2003).

Thus, as a result of the capacity of biomass production and atmospheric $\mathrm{N}$ fixation by microorganisms in symbiosis with legumes, macassar and pigeon pea beans are recommended (BRANDÃO et al., 2017), thereby contributing to the $\mathrm{N}$ metabolism of microbial activity.

In this study, the macassar bean presented a higher MBC content and the increase of manure doses was directly proportional to increases of this indicator. According to Vargas and Scholles (2000), the presence of legumes increases the availability of $\mathrm{N}$ in the soil, which in the presence of $\mathrm{C}$, increases the microbial activity.

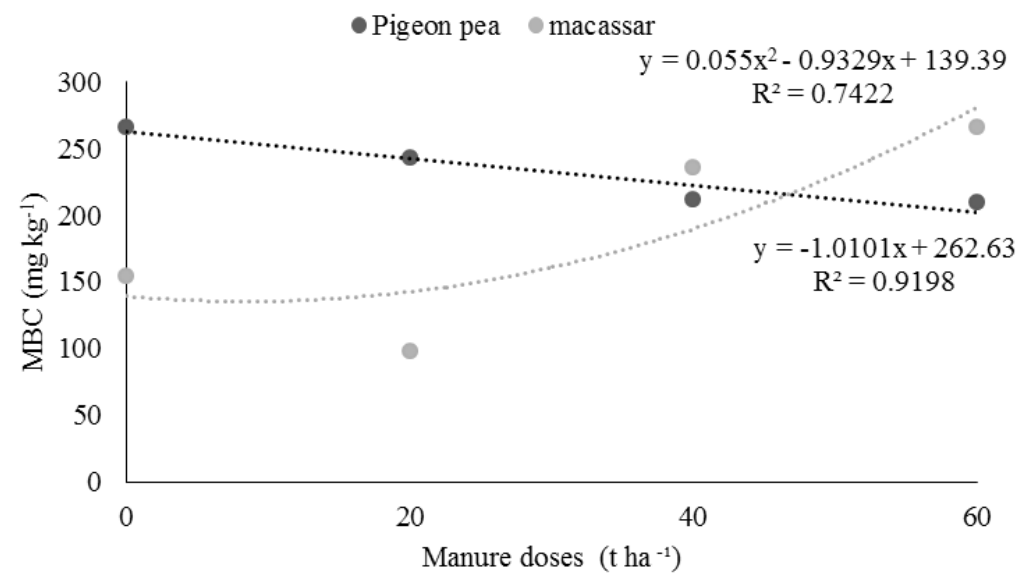

Figure 4. Microbial biomass carbon in soil cultivated with maize as a function of the doses of cattle manure associated with green manuring, macassar and pigeon pea beans.

The acid phosphatase found in soil cultivated with maize at different doses of manure and green manure (macassar and pigeon pea) did not fit the polynomial regression model, but the enzyme activity was on average 3,682 $\mu \mathrm{g} \mathrm{p-nitrophenol} \mathrm{g}^{-1}$ soil h $^{-1}$ (Figure 5). The enzymatic activity in soils cultivated with green manure was between 2.34 to 3.25 (Pigeon pea) and 
1.12 to 2.03 (Macassar) times greater than the control (absolute and chemical) treatment, respectively. This increase may be related to the low phosphorus (P) supply to the plants, thus increasing their enzymatic activity (DICK; SANDOR; EASH, 1994). Pigeon pea may be competing with maize plants for the use of phosphorus (P), leaving such soils with lower phosphorus availability and consequently, contributing to the increase in acid phosphatase activity. In addition, crop biomass and green manure treatments may also stimulate plant growth, metabolism, microbial biomass and consequently, enzymatic production and activity (PIOTROWSKA; WILCZEWSKI, 2012).

According to Matsuoka, Mendes and Loureiro (2003), these results can be attributed to the quality of organic matter, which serves as the main source of nutrients for plant growth. Therefore, if there is no organic matter with quality, even with the low availability of $\mathrm{P}$ for the plants, the enzyme will not be activated because there will be no energy source to carry out its activities. Another factor that explains these results is that usually, areas with legume present large amounts of organic carbon, as well as organic phosphorus contained in the soil microbial biomass and low availability of inorganic phosphorus (LANNA et al., 2010).

The system of maize planting using legumes as green manure (pigeon pea and macassar beans) recorded the highest level of acid phosphatase enzyme activity compared to other conventional crops (synthetic manure and without fertilizer). These results corroborate the findings of Raghothama and Karthikeyan (2005), who stated that the higher the availability of soluble $\mathrm{P}$ in the soil, the lower the activity of the enzyme, acid phosphatase. According to the authors, plants and microorganisms release acid phosphatase when there is low availability of soluble $\mathrm{P}$ in the soil.

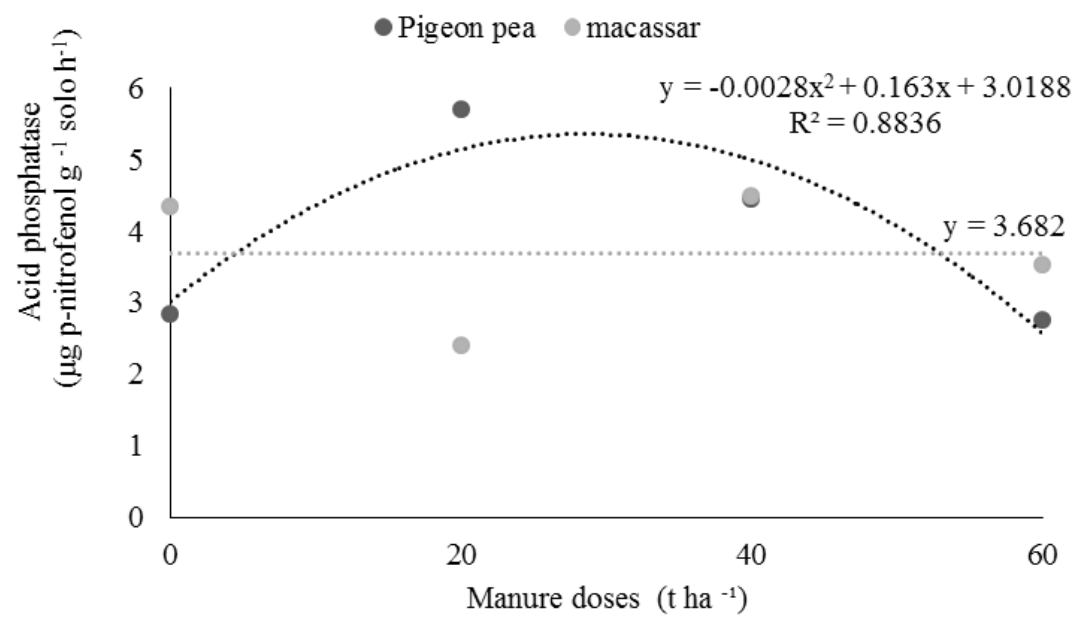

Figure 5. Acid phosphatase in soil cultivated with maize as a function of the doses of cattle manure associated with green manuring, Macassar and Pigeon pea beans.

The alkaline phosphatase found in soil cultivated with maize showed significant differences between the treatments and the chemical control, with the highest values being recorded at the $40 \%$ cattle manure dose with $48.27 \%$ increase in relation to the chemical control (Figure 6). However, the values obtained from alkaline phosphatase as a function of manure doses for pigeon pea did not fit the polynomial regression model.

Treatments with lower doses of manure (lower levels of organic matter added) were the ones that presented the lowest content of this activity, because if there is no available $\mathrm{P}$ for the plant, the activity of phosphatase must be activated, but to be activated it must have quality organic matter. Such data corroborate the findings of Wang et al. (2012), who stated that as the organic matter in the soil decreases, the activity of phosphatase will also decrease. The data revealed that there was less need for the alkaline phosphatase enzyme to exert its function, so that phosphorus becomes available to the plants in acidic soil.

The values obtained for the urease enzyme activity did not fit any model of statistical significance; therefore, there was no significant difference between the means of treatments. Nitrogen fertilization may increase the activity of some enzymes of the $\mathrm{C}$ and $\mathrm{P}$ cycle, such as cellulases (SINSABAUGH et al., 2005) and phosphatases (GUO et al., 2011). On the other hand, it may decrease the activity of $\mathrm{N}$-cycling enzymes such as urease and it is known that with the use of green fertilization, through legume plants to the soil, the $\mathrm{N}$ content is the fastest increasing nutrient. 


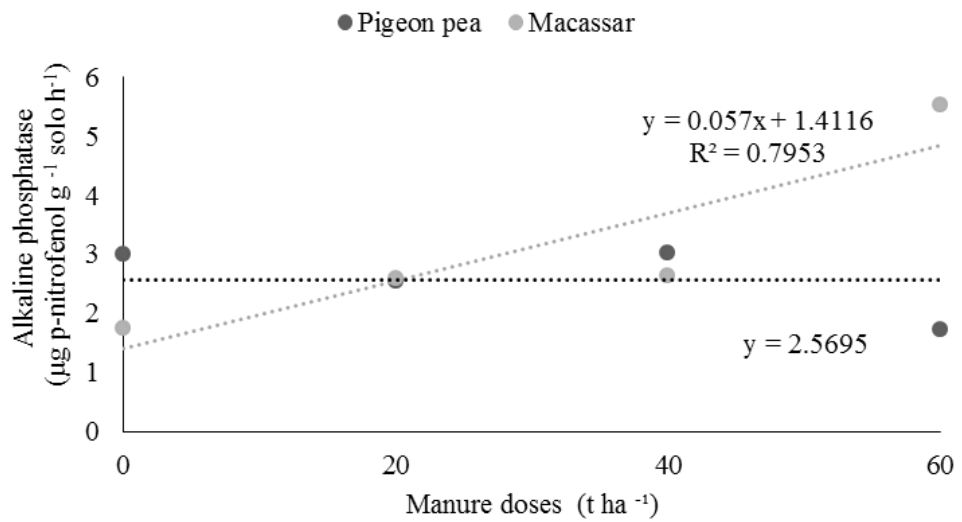

Figure 6. Alkaline phosphatase in soil cultivated with maize as a function of the doses of cattle manure associated with green manuring, Macassar and Pigeon pea beans.

\section{CONCLUSIONS}

The use of legumes with cattle manure allows the production of maize plants with higher yield characteristics compared to those cultivated using mineral fertilizer, with emphasis on macassar beans and higher doses of cattle manure (40 and 60\%). Soils with macassar showed higher carbon microbial biomass contents with higher doses of cattle manure. Leguminous and cattle manure influence the biochemical quality of soils cultivated with maize, with higher rates of enzymatic activities in soils with macassar green manure and higher doses of cattle manure.

\section{ACKNOWLEDGEMENTS}

The authors are grateful to $\mathrm{CNPq}$ for financial support (Process 481436 / 2010-3 and $562584 / 2010-2)$ and the corresponding author's productivity grant (306401/2015-0) and to CAPES for student grant.

\section{REFERENCES}

ALCÂNTARA, F. A. et al. Adubação verde na recuperação da fertilidade de um Latossolo vermelho escuro. Pesquisa Agropecuária Brasileira, Brasília, v. 35, n. 3, p. 277-288, 2000.

BASI, S. et al. Influência da adubação nitrogenada sobre a qualidade da silagem de milho. Revista Brasileira de Tecnologia Aplicada nas Ciências Agrárias, Guarapuava, v. 4, n. 3, p. 219-234, 2011.

BELO, E. S. et al. Decomposição de diferentes resíduos orgânicos e efeito na atividade microbiana em um Latossolo Vermelho de Cerrado. Global Science and Technology, Rio Verde, v. 5, n. 3, p. 107-116, 2012.

BODDEY, R. M. et al. Carbon accumulation at depth in Ferralsols under zero-till subtropical agriculture. Global Change Biology, Illinois, v. 16 , n. 2 , p. $784-795,2010$.

BRANDÃO, S. S. et al. Adubação verde contribuindo para ciclagem de nutrientes em ambientes irrigados no semiárido brasileiro. Journal of Environmental Analysis and Progress, Recife, v. 2, n. 4, p. 519-525, 2017.

BURNS, R. G. et al. Soil enzymes in a changing environment: current knowledge and future directions. Soil Biology and Biochemistry, Leicestershire, v. 58, n. 1, p. 216-234, 2013.

CAMARA, F. T. et al. Produtividade de milho verde em função do manejo da adubação na região do Cariri cearense. Revista Cultivando o Saber, Cascavel, v. 9, n. 4, p. 412-425, 2016.

CARDOSO, M. J. et al. Produtividade e espiga verde de milho sob diferentes níveis de nitrogênio. Horticultura Brasileira, Brasília, v. 28, n. 2, p. S3786-S3789, 2010.

CHAER, M. G.; TÓTOLA, M. R. Impacto do manejo de resíduos orgânicos durante a reforma de plantios de eucalipto sobre indicadores de qualidade do solo. Revista Brasileira de Ciência do Solo, Viçosa, v. 31, n. 6, p. 1381-1396, 2007.

CUNHA, E. Q. et al. Sistemas de preparo do solo e culturas de cobertura na produção orgânica de feijão e Milho. II - atributos biológicos do solo. Revista Brasileira de Ciência do Solo, Viçosa, v. 35, n. 1, p. 603-611, 2011.

DICK, R. P.; SANDOR, J. A.; EASH, N. S. Soil enzyme activities after 1500 years of terrace agriculture in the colcavalley, peru. Agriculture Ecosystems Environment, Switzerland, v. 50, n. 2, p. 123-131, 1994.

DOAN, T. T. et al. Impact of compost, vermicompost and biochar on soil fertility, maize 
yield and soil erosion in Northern Vietnam: A three year mesocosm experiment. Science of the Total Environment, Barcelona, v. 514, n. 1, p. 147-154, 2015.

GUO, P. et al. Responses of soil microbial biomass and enzymatic activities to fertilizations of mixed inorganic and organic nitrogen at a subtropical forest in East China. Plant and Soil, Crawley, v. 338, n. 12, p. 355-366, 2011.

HEINRICHS, R. et al. Doses de nitrogênio em cobertura na cultura do milho. Revista Científica Eletrônica Agronomia, Graça, v. 2, n. 4, p. 1-5, 2003.

KANDELER, E.; GERBER, H. Short-term assay of soil uréase activity using color-imetric determination of ammonium. Biology and fertility of Soils, Florence, v. 6, n. 1, p. 68-72, 1988.

LANNA, A. C. et al. Atividade da fosfatase Ácida no solo com feijoeiro influenciado pela cobertura vegetal e sistemas de plantio. Revista Brasileira de Ciência do Solo, Viçosa, v. 34, n. 6, p. 1933-1939, 2010.

MATSUOKA, M.; MENDES, I. C.; LOUREIRO, M. F. Biomassa microbiana e atividade enzimática em solos sob vegetação nativa e sistemas agrícolas anuais e perenes na região de Primavera do Leste (MT). Revista Brasileira de Ciência do Solo, Viçosa, v. 27, n. 3, p. 425-433, 2003.

MEDEIROS, E. V. et al. Absolute and specific enzymatic activities of sandy entisol from tropical dry forest, monoculture and intercropping areas. Soil and Tillage Research, Kiel, v. 145, n. 1, p. 208-215, 2015.

MEDEIROS, E. V. et al. Soil organic carbon, microbial biomass and enzyme activities responses to natural regeneration in a tropical dry region in Northeast Brazil. Catena, Amsterdam, v. 151, n. 1, p. 137-146, 2017.

MENDONÇA, E. S.; MATOS, E. S. Matéria orgânica do solo: Métodos de análises. 1. ed. Viçosa, MG: UFV. 2005, 107 p.

PIOTROWSKA, A.; WILCZEWSKI, E. Effects of catch crops cultivated for green manure and mineral nitrogen fertilization on soil enzyme activities and chemical properties. Geoderma, Beijing, v. 189, n. 1, p. 72-80, 2012

RAGHOTHAMA, K. G.; KARTHIKEYAN, A. S. Phosphate acquisition. Plant and Soil, Crawley, v. 274, n. 1, p. 37-49, 2005.
RITCHIE, S. W.; HANWAY, J. J.; BENSON, G. O. How a corn plant develops. Ames: Iowa State University of Science and Technology, 1993. 26 p. (Special report, 48).

ROSA, D. M. et al. Desempenho da cultura do milho implantada sobre resíduos culturais de leguminosas de verão em sistema plantio direto. Semina: Ciências Agrárias, Londrina, v. 32, n. 4, p. $1287-$ 1296, 2011.

SANGOI, L. et al. A aplicação de nitrogênio em cobertura não aumento o rendimento de grãos do trigo cultivado na presença do alumínio. Ciência Rural, Santa Maria, v. 38, n. 4, p. 912-920, 2008.

SINSABAUGH, R. L. et al. Extracellular enzyme activities and soil organic matter dynamics for northern hardwood forests receiving simulated nitrogen deposition. Biogeochemistry, Corvallis, v. 75 , n. 2 , p. 201-215, 2005

SOUZA, E. P.; BRAGA, M. J.; CUNHA, D. A. Interdependência dos preços do milho no sul brasileiro. Revista de Economia, Rio de Janeiro, v. 36, n. 2, p. 71-90, 2010.

TABATABAI, M. A. Soil enzymes. In: MICKELSON, S. H.; WEAVER, R. W. (Eds.). Methods of Soil Analysis. Part 2: Microbiological and Biochemical Properties. Madison: Soil Science Society of America, 1994. v. 5, cap. 1, p. 778-833.

TROLOVE, S. N. et al. Progress in selected areas of rhizosphere on $\mathrm{P}$ acquisition. Australian Journal of Soil Research, Sydney, v. 41, n. 3, p. 471-499, 2003

UNITED STATES DEPARTMENT OF MARKETING SERVICE - USDA. AMS. Grain Transportation Report, Washington, 2016. 21 p.

VARGAS, L. K.; SCHOLLES, D. Biomassa microbiana e produção de $\mathrm{C}-\mathrm{CO}_{2}$ e $\mathrm{N}$ mineral de um podzólico vermelho-escuro submetido a diferentes sistemas de manejo. Revista Brasileira de Ciência do Solo, Viçosa, v. 24, n. 1, p. 35-42, 2000

WANG, B. et al. Changes in soil nutrient and enzyme activities under different vegetations in the Loess Plateau area, Northwest China. Catena, Amsterdan, v. 92, n. 1, p. 186-195, 2012.

WALTER, I. et al. Short-term effects of poultry litter application on silage maize and soil chemical properties. Compost Science and Utilization, Ohio, v. 17, n. 3, p. 189-196, 2009 